\title{
Arg-Gly-Asp-Ser-Selective Adhesion and the Stabilization of Long- Term Potentiation: Pharmacological Studies and the Characterization of a Candidate Matrix Receptor
}

\author{
Ben A. Bahr, ${ }^{1}$ Ursula Staubli, ${ }^{2}$ Peng Xiao, ${ }^{1}$ Daniel Chun, ${ }^{2}$ Zhan-Xin Ji, ${ }^{2}$ Everard T. Esteban, ${ }^{1}$ and Gary Lynch ${ }^{1}$ \\ ${ }^{1}$ Center for the Neurobiology of Learning and Memory, University of California, Irvine, California 92697, and ${ }^{2}$ Center for \\ Neural Science, New York University, New York, New York 10003
}

Peptides known to block the extracellular interactions of adhesion receptors belonging to a subclass of the integrin family were tested for their effects on the stabilization of long-term potentiation (LTP) in hippocampal slices. Theta burst stimulation delivered after infusions of Gly-Ala-Val-Ser-Thr-Ala (GAVSTA) resulted in a potentiation effect that decayed steadily over a period of $40 \mathrm{~min}$; LTP elicited in the presence of inactive control peptides remained stable over this time period. GAVSTA had no detectible influence on baseline responses, induction processes, or the initial degree of potentiation. Infusions of integrin antagonists after application of theta bursts also resulted in the occurrence of a decremental form of LTP. Affinity chromatography was then used in an effort to identify targets of the structurally dissimilar integrin blockers that disrupt LTP stabilization. Both integrin antagonists Gly-Arg-GlyAsp-Ser-Pro and GAVSTA eluted a major species of $55 \mathrm{kDa}$ (synaptegrin-1) from GRGDSP-affinity columns that had been loaded with solubilized synaptic membranes; lesser concentrations of three polypeptides of $\sim 20,27$, and $30 \mathrm{kDa}$ were also collected. Synaptegrin-1 was labeled by antibodies to the RGDS-binding integrin $\alpha_{5} \beta_{1}$. In addition, the synaptegrin, as well as the $27 \mathrm{kDa}$, protein was found to copurify with pre- and postsynaptic markers during the isolation of forebrain synaptosomes. These results indicate that a matrix recognition event occurring several minutes after induction of LTP is a necessary step in the stabilization of potentiated synapses; they also identify an integrin-like matrix receptor of $55 \mathrm{kDa}$ that may contribute to this event.

Key words: GAVSTA; hippocampus; long-term potentiation; matrix receptors; RGDS-binding proteins; synaptic adhesion molecules; synaptegrin-1
Long-term potentiation (LTP) is characterized by its rapid induction (Bliss and Lomo, 1973; Gustafsson et al., 1989) and remarkable stability (Bliss and Gardner-Medwin, 1973; Staubli and Lynch, 1987). Although much has been learned about the first of these properties, the cellular changes responsible for the second remain unclear. Electron microscopic analyses indicate that LTP is associated with alterations in the morphology of the postsynaptic region (Lee et al., 1979, 1980; Desmond and Levy, 1983; Chang and Greenough, 1984; Wallace et al., 1991; Geinisman et al., 1993; Buchs and Muller, 1996), and effects of this kind might persist for very long periods. In addition, antagonists that block cell-cell and cell-matrix interactions prevent the stabilization of LTP (Staubli et al., 1990; Xiao et al., 1991; Lüthi et al., 1994; Rønn et al., 1995; see also Muller et al., 1996; Nosten-Bertrand et al., 1996). The antagonists act on two separate classes of cell surface adhesion molecules: (1) neural cell adhesion molecules (NCAMs) of the immunoglobulin superfamily (see Persohn et al., 1989; Schachner and Martini, 1995), and (2) integrin-type matrix receptors that are assembled from a variety of subunits and are involved in signaling pathways (see Schwartz and Ingber, 1994; Clark and Brugge, 1995; Rosales et al., 1995). The anatomical and pharmacological results

Received Sept. 16, 1996; revised Dec. 2, 1996; accepted Dec. 3, 1996.

This work was supported by Air Force Office of Scientific Research Grant 92-J0307 (G.L.), a University of California Committee of 1000 Young Investigator Award (B.A.B.), and a New York University Whitehead Fellowship (U.S.).

Correspondence should be addressed to Dr. Gary Lynch, Center for the Neurobiology of Learning and Memory, University of California, Irvine, CA 92697-3800.

Dr Ziao's present address: Department of Biology, South China Normal University, Guangzhou, GD 510631 People's Republic of China.

Copyright (C) 1997 Society for Neuroscience 0270-6474/97/171320-10\$05.00/0 concerning LTP could be related; that is, adhesion receptors play important roles in the assembly of pericellular matrices (Akiyama et al., 1989; Fogerty et al., 1990; Wu et al., 1993, 1995ab) and in the organization and maintenance of contact morphology (Horwitz et al., 1986; Burridge et al., 1988; Albelda and Buck, 1990; Otey et al., 1990; Hynes, 1992; Arregui et al., 1994). Thus, activation or insertion of such receptors immediately after LTP induction could promote the stable rearrangement of the synaptic region, and in this way, convert the initial potentiation into a persistent and not readily disrupted state.

Previous studies on the potential contributions of integrins to LTP (Staubli et al., 1990; Xiao et al., 1991) used peptides containing the amino acid sequence Arg-Gly-Asp-Ser (RGDS), which are known to compete with extracellular matrix proteins for the binding site of a subgroup of the adhesion receptors (Pierschbacher and Ruoslahti, 1984; Ruoslahti and Pierschbacher, 1987). A second class of antagonists mimics the matrix binding domain of RGDS-binding integrins and blocks the adhesive interactions between these integrins and their targets (Brentani et al., 1988; Pasqualini et al., 1989). Accordingly, the first goal of the present experiments was to test whether one such antagonist, the peptide Gly-Ala-Val-Ser-Thr-Ala (GAVSTA), disrupts LTP stabilization as do RGDS peptides. A second objective was to determine whether involvement of adhesion chemistries is an early versus late stage event in the stabilization of LTP. This was tested by infusing RGDS peptides into slices immediately after or several minutes after LTP had been induced.

The initial findings obtained with RGDS peptides in LTP 
experiments prompted a search for integrins and/or integrin-like molecules in synaptic membrane fractions. Somewhat surprisingly, immunochemical analyses using a panel of antibodies failed to detect proteins equivalent in size to integrin subunits (Bahr et al., 1991a,b). They did, however, identify smaller species (27, 40, and $55 \mathrm{kDa}$ ) that are concentrated in synaptosomal membranes and that possess integrin epitopes. Additional work confirmed that two of these proteins exhibit integrin-like matrix recognition and are brain-specific molecules (see Bahr et al., 1991b, 1997; Bahr and Lynch, 1992). Immunocytochemical studies using similar antibodies found patterned staining in the adult hippocampus indicative of the presence of integrin epitopes in synapses (Grooms et al., 1993; Jones and Grooms, 1995; Einheber et al., 1996; Jones, 1996). These observations strongly suggest that integrin-like receptors targeted by the RGDS peptides used in the LTP experiments are present in hippocampal synapses. The third section of the present study tested this conclusion by sampling for RGDS-binding proteins in synaptosomal membranes and assessing the extent to which such proteins comigrate with synaptic markers across subcellular fractions.

\section{MATERIALS AND METHODS}

Antibodies and chemicals. Polyclonal antibodies (goat anti- $\alpha_{5} \beta_{1}$ ) to the Chinese hamster ovarian fibronectin receptor (Pytela et al., 1985; Schreiner et al., 1989; Schwarz et al., 1989) were generously provided by Dr. R.L. Juliano (Department of Pharmacology, University of North Carolina School of Medicine, Chapel Hill, North Carolina). Rabbit antibodies to the AMPA receptor subunits GluR1 and GluR2/3 were prepared by injecting rabbits with the respective $\mathrm{C}$-terminal sequences and then subjecting the antisera to affinity purification, as described (Wenthold et al., 1992). Antibodies against the cytoplasmic domain of the $\beta_{1}$ protein (affinity-purified) and the $\alpha_{\mathrm{v}} \beta_{3}$ vitronectin receptor from human placenta were obtained from Chemicon International (Temecula, CA). The monoclonal antibody anti-synaptophysin and $N$-octyl- $\beta$-D-glucopyranoside were obtained from Sigma (St. Louis, $\mathrm{MO}$ ). Nitrocellulose paper and alkaline phosphatase-conjugated antibodies to rabbit, mouse, and goat IgGs were obtained from BioRad Laboratories (Richmond, CA). Fibronectin-agarose was obtained from Calbiochem (San Diego, CA). The peptides GAVSTA, RGDS, and Ala-Ser-Gly (ASG) and tetraglycine were obtained from BACHEM Biosciences (King of Prussia, PA), Gly-Arg-Gly-Asp-Ser-Pro (GRGDSP) and Gly-Arg-Ala-Asp-Ser-Pro (GRADSP) from Calbiochem, and Gly-Arg-Gly-Asp-Ser-Pro-Lys (GRGDSPK) from Telios Pharmaceuticals, (San Diego, CA). All other materials were from usual commercial sources, unless otherwise noted.

Hippocampal slice physiology. Male Sprague Dawley rats (60 to $90 \mathrm{~d}$ old) in good condition were killed by metofane anesthesia and decapitation. The brains were rapidly removed and placed into artificial CSF (ACSF) containing (in mM): $124 \mathrm{NaCl}, 10$ glucose, $3 \mathrm{KCl}, 1.25 \mathrm{KH}_{2} \mathrm{PO}_{4}$, $2.5 \mathrm{MgSO}_{4}, 3.4 \mathrm{CaCl}_{2}, 26 \mathrm{NaHCO}_{3}, 2$ ascorbate, $\mathrm{pH} 7.4$, at $0^{\circ} \mathrm{C}$. Hippocampi were immediately dissected free and $400 \mu \mathrm{m}$ slices were cut perpendicular to the septo-temporal axis. The slices were then transferred to an interface chamber where they were maintained at $35^{\circ} \mathrm{C}$ while being superfused with a humidified oxygen/carbon dioxide mixture (95:5; $\sim 1 \mathrm{l} / \mathrm{min})$ and subfused with ACSF $(0.5 \mathrm{ml} / \mathrm{min})$ saturated with the same gas mixture for a $60 \mathrm{~min}$ equilibration period. A pulled-glass recording electrode containing $2 \mathrm{M} \mathrm{NaCl}(\sim 5 \mathrm{M} \Omega)$ was subsequently positioned into the stratum radiatum of CA1b, and field EPSPs were elicited every $20 \mathrm{sec}$ by delivering stimulation pulses $(0.1 \mathrm{msec}, 0.1 \mathrm{~Hz})$ to two bipolar nichrome electrodes $(25 \mu \mathrm{m}$, twisted) positioned equidistant from the recording electrode among the Schaffer commissural projections in CA1a and CA1c. The two pathways were deemed independent because of the lack of any heterosynaptic paired-pulse facilitation. The intensity of stimulation was adjusted in each case to produce a dendritic field potential that was $50-60 \%$ of the maximum spike-free response $(1-1.5 \mathrm{mV})$, and recordings were collected until a stable baseline was present for 10-20 min; if the latter condition did not occur, the slice was not included in the study. The two pathways were routinely tested for overlap by applying twice the normal current via the individual stimulation electrodes. Response parameters were measured during and after 50-90 min of infusion with integrin antagonists or control peptides. In some cases, baseline responses were continually recorded in one pathway while LTP was induced in the second pathway using a theta burst stimulation (TBS) paradigm (Larson et al., 1986; Larson and Lynch, 1988) consisting of 10 high-frequency bursts (4 pulses at $100 \mathrm{~Hz}$ ) delivered at five bursts/sec; the duration of the stimulation pulses was doubled during the train of bursts. TBS was delivered to the first pathway $40 \mathrm{~min}$ after being delivered to the second. In other experiments, RGDS peptides were infused immediately after or $10 \mathrm{~min}$ after applying TBS to the second pathway. Potentiation was tabulated as the percent increase above the baseline initial slope.

Synaptic plasma membrane isolation. Sprague Dawley rats (groups of 3-5) were killed by metofane anesthesia and decapitation, and each brain was rapidly cooled, removed from the skull, and dissected in ice-cold homogenization buffer (HB) consisting of $0.32 \mathrm{M}$ sucrose, $5 \mathrm{~mm}$ HEPES, $\mathrm{pH} 7.4,1 \mathrm{~mm}$ EDTA, $1 \mathrm{~mm}$ EGTA, and the following protease inhibitors: $4 \mu \mathrm{g} / \mathrm{ml}$ antipain, $2 \mu \mathrm{g} / \mathrm{ml}$ aprotinin, $2 \mu \mathrm{g} / \mathrm{ml}$ leupeptin, 2 $\mu \mathrm{g} / \mathrm{ml}$ pepstatin $\mathrm{A}$, and $0.4 \mathrm{~mm}$ phenylmethylsulfonyl fluoride (added fresh). The brainstem and cerebellum were first separated from the endbrain which, after removal of the olfactory bulbs, was dissected into neocortex, hippocampus, striatum-rich material, and thalamus-rich material as follows. The frontal third of the endbrain was separated by a coronal cut, and the tissue under the callosal ring was collected as striatum-rich tissue. The loosely attached core of the caudal two-thirds of the endbrain containing mostly thalamus and hypothalamus was called thalamus-rich tissue. The neocortical tissue remaining after folding out and detaching the hippocampus was combined with the nonstriatal tissue from the frontal one-third of the endbrain. The pooled regions or whole brains from simultaneous dissections were quickly homogenized in HB using a Potter-Elvehjem tissue grinder for $30 \mathrm{sec}$ at high speed and then subjected to the following procedure by Dunkley et al. (1986) to isolate synaptosomes. Homogenates were centrifuged at $1090 \mathrm{~g}$ for $10 \mathrm{~min}$, and the resultant supernatants centrifuged again at $14,600 \mathrm{~g}$ for $20 \mathrm{~min}$. The P2 pellets were resuspended in 1-2 $\mathrm{ml} \mathrm{HB}$ and slowly layered over freshly prepared $4 \times 2 \mathrm{ml}$ gradients consisting of $3,10,15$, and $25 \%$ (vol/vol) Percoll in HB (each solution was adjusted to $\mathrm{pH} 7.4$ immediately before use). The density gradients were centrifuged in a fixed-angled rotor at $45,700 \mathrm{~g}$ for exactly 5 min (not including acceleration and deceleration time). The interfacial fractions designated as 3 and 4 , which are concentrated in synaptic markers (see Dunkley et al., 1986), were pooled and washed in HB by centrifugation $(40,000 \mathrm{~g}$ for $30 \mathrm{~min})$. Alternatively, all interfacial fractions (1-5) were carefully removed and washed in HB. The resulting pellets were lysed in 2-10 $\mathrm{ml}$ of hyposmotic buffer containing $8 \mathrm{~mm}$ HEPES, pH 7.4, $1 \mathrm{~mm}$ EDTA, $0.3 \mathrm{~mm}$ EGTA, and the protease inhibitors mentioned above. Membranes were isolated and washed by repeated centrifugation-resuspension cycling in $25 \mathrm{~mm}$ HEPES, 100 $\mathrm{mm} \mathrm{NaCl}, 0.5 \mathrm{~mm}$ EDTA, $\mathrm{pH}$ 7.4, with protease inhibitors. Protein content for soluble and membrane fractions was determined using the BioRad Protein Assay with a BSA standard. The fractions were finally divided into aliquots and stored at $-80^{\circ} \mathrm{C}$.

Affinity chromatography. Thawed synaptosomal membranes (SPMs; 3-4 $\mathrm{mg}$ protein at $0.8 \mathrm{mg} / \mathrm{ml}$ ) in column buffer containing $35 \mathrm{~mm} \mathrm{Tris,} \mathrm{pH}$ $7.74,150 \mathrm{~mm} \mathrm{NaCl}, 1 \mathrm{mM} \mathrm{CaCl}_{2}, 1 \mathrm{mM} \mathrm{MgCl}, 20 \mu \mathrm{g} / \mathrm{ml}$ antipain, $2 \mu \mathrm{g} / \mathrm{ml}$ aprotinin, $40 \mu \mathrm{g} / \mathrm{ml}$ calpain inhibitor I, $2 \mu \mathrm{g} / \mathrm{ml}$ leupeptin, $2 \mu \mathrm{g} / \mathrm{ml}$ pepstatin $\mathrm{A}$, and $0.3 \mathrm{~mm}$ fresh phenylmethylsulfonyl fluoride were solubilized with $150 \mathrm{~mm} N$-octyl- $\beta$-D-glucopyranoside or $1 \%$ (wt/vol) Triton X-100 (the latter included $10 \%$ glycerol and $0.01 \%$ phosphatidylcholine) on ice for $1 \mathrm{hr}$. The detergent-membrane suspensions were homogenized in an etched-glass Potter-Elvehjem tissue grinder for $30 \mathrm{sec}$ at high speed, and nonsoluble material was removed by centrifugation at $50,400 \mathrm{~g}$ for 30 $\min$ at $4^{\circ} \mathrm{C}$. The clear supernatants were slowly applied to immobilized GRGDSPK (8-10 $\mathrm{mg}$ per $4 \mathrm{ml}$ column) on activated sepharose 4B (Pharmacia Biotech, Piscataway, NJ) or to fibronectin-agarose, over many hours at $4^{\circ} \mathrm{C}$. Each column was preequilibrated in column buffer with either $30 \mathrm{~mm} N$-octyl- $\beta$-D-glucopyranoside or $0.1 \%$ Triton X-100 at $4^{\circ} \mathrm{C}$ and washed with $\sim 10$ column volumes of the same solution after the loading of soluble membranes. RGDS-binding proteins were eluted by adding integrin antagonists $(3 \mathrm{~mm})$ to the wash solution. Individual or pooled fractions of the eluant were concentrated to appropriate volumes with Centricon-10 concentrators (Amicon, Danvers, MA) before electrophoresis and immunoblotting.

Electrophoresis and immunoblotting. Samples were treated with $2.5 \%$ (wt/vol) SDS in the presence of $3 \%$ ( $\mathrm{vol} / \mathrm{vol})$ 2-mercaptoethanol and incubated at $100^{\circ} \mathrm{C}$ for $5 \mathrm{~min}$. The denatured proteins were then separated by electrophoresis on polyacrylamide linear gradient gels (3-17\% $\mathrm{wt} / \mathrm{vol}$ ), after which the proteins were silver-stained, coomassie-stained, 
Table 1. Comparison of response parameters in the presence of GAVSTA and control peptides

Baseline response characteristics (mean \pm SEM)

\begin{tabular}{|c|c|c|c|c|c|c|}
\hline \multirow[b]{2}{*}{ Peptide $(n)$} & \\
\hline & Initial slope & Amplitude & Area & Rise $t_{1 / 2}$ & Decay $t_{1 / 2}$ & $1 / 2$ width \\
\hline Control (16) & $\begin{array}{l}0.60 \pm 0.02 \\
\left(-\mathrm{mV} \cdot \mathrm{ms}^{-1}\right)\end{array}$ & $\begin{array}{l}1.29 \pm 0.04 \\
(-\mathrm{mV})\end{array}$ & $\begin{array}{l}8.25 \pm 0.37 \\
(\mathrm{mV} \cdot \mathrm{msec})\end{array}$ & $\begin{array}{l}1.95 \pm 0.06 \\
(\mathrm{msec})\end{array}$ & $\begin{array}{l}3.96 \pm 0.14 \\
(\mathrm{msec})\end{array}$ & $\begin{array}{l}5.91 \pm 0.23 \\
(\mathrm{msec})\end{array}$ \\
\hline GAVSTA (16) & $0.59 \pm 0.03$ & $1.38 \pm 0.05$ & $8.94 \pm 0.40$ & $2.09 \pm 0.05$ & $3.86 \pm 0.15$ & $6.07 \pm 0.20$ \\
\hline
\end{tabular}

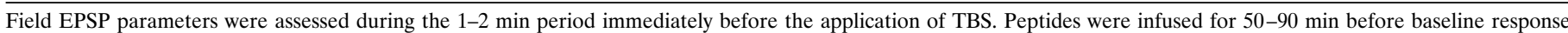
characteristics were measured. Control: $2 \mathrm{~mm}$ ASG or $0.8 \mathrm{~mm}$ GRADSP, measured from 16 pathways. GAVSTA: 0.8 mm peptide in 16 pathways.

or transferred to nitrocellulose $(0.2 \mu \mathrm{m}$ pore size $)$ for $1-2 \mathrm{hr}$ or $24 \mathrm{hr}$ with blotting systems from BioRad Laboratories. Immunodetection of transferred proteins used the following antibodies diluted to the indicated concentration in $1.5 \%(\mathrm{wt} / \mathrm{vol})$ nonfat dry milk: anti- $\alpha_{5} \beta_{1}$ (diluted 500 - to 2000 -fold), anti- $\alpha_{\mathrm{v}} \beta_{3}(1: 500)$, anti- $\beta_{1}(5 \mu \mathrm{g} / \mathrm{ml})$, anti-GluR1 $(2 \mu \mathrm{g} / \mathrm{ml})$, anti-GluR2/3 $(4 \mu \mathrm{g} / \mathrm{ml})$, and anti-synaptophysin $(50 \mathrm{ng} / \mathrm{ml})$. After a $12-16$ $\mathrm{hr}$ incubation at $4^{\circ} \mathrm{C}$ with agitation, the blots were stained with anti-IgGalkaline phosphatase conjugates, using the 5-bromo-chloro-3-indolyl phosphate/nitro blue tetrazolium substrate system. Color development of immunoreactive bands was terminated before maximal intensity was reached to avoid saturation and allow comparative studies within each blot. In some cases, the optical densities and image areas of the labeled antigens were quantitatively compared within single immunoblots using a computerized image analysis system; the total immunoreactivity [(optical density - background) $\times$ image area)] for each band was determined from these values. Calibration of immunoblots using prestained protein molecular weight standards allowed the determination of the $M_{\mathrm{r}}$ for pertinent species.

\section{RESULTS}

Slices treated with the hexapeptide antagonist GAVSTA for 50-90 min exhibited no evident physiological disturbances and, as shown in Table 1, had field EPSPs that were similar in size and waveform to those recorded in slices infused with inactive control peptides. TBS resulted in an immediate potentiation of the synaptic responses that was comparable in both the GAVSTA and control slices (Fig. 1); the slopes of the field EPSPs measured at 2 min after TBS were increased by $54 \pm 22 \%$ (mean \pm SD) in the GAVSTA group (Fig. $1 a ; n=16$ ) and by $66 \pm 26 \%$ in slices treated with control peptide $(n=16)$. These values accord well with those reported in the literature for the degree of initial potentiation elicited by the TBS paradigm. The magnitude of potentiation decayed over a 40 min recording period to a much greater degree in slices infused with GAVSTA than was the case for peptides that do not antagonize integrins (Fig. 1d). Comparisons made at the $40 \mathrm{~min}$ time point (see responses superimposed with baseline EPSPs in Fig. 1, $b$ vs $c$ ) indicated that the average potentiation in the experimental group was $20 \pm 15 \%$ versus $49 \pm$ $18 \%$ in the controls $(p<0.0001$; unpaired, two-tailed $t$ test $)$. In addition, the degree of potentiation continued to decrease between 30 and 40 min after TBS in the GAVSTA slices (Fig. 1d), suggesting that the peptide interferes with the stability of LTP rather than simply reducing its magnitude. Potentiation of a size commonly reported was, however, maintained in the preparations infused with control peptides. In particular, slices treated with the inactive hexapeptide GRADSP exhibited stable LTP at $40 \mathrm{~min}$ after TBS $(46 \pm 24 \%, n=6)$.

Pathways used in 10 of the above GAVSTA experiments were tested for effects of the peptide before induction of LTP (Fig. 1d, open circles). The baseline responses did not decrease over a 40 min period before application of TBS. In four of the slices, two pathways were simultaneously recorded; the baseline was continually monitored in one pathway while LTP was induced in the second. While potentiation in experimental pathways decayed to

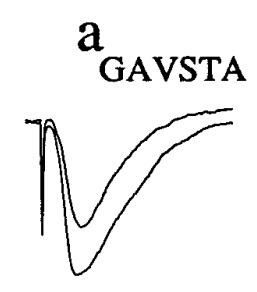

$2 \mathrm{~min}$ b GAVSTA

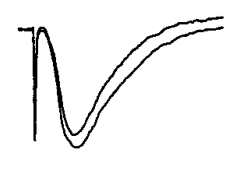

$40 \mathrm{~min}$

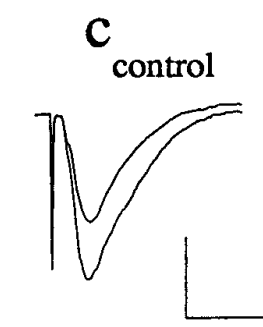

$40 \mathrm{~min}$ post-TBS

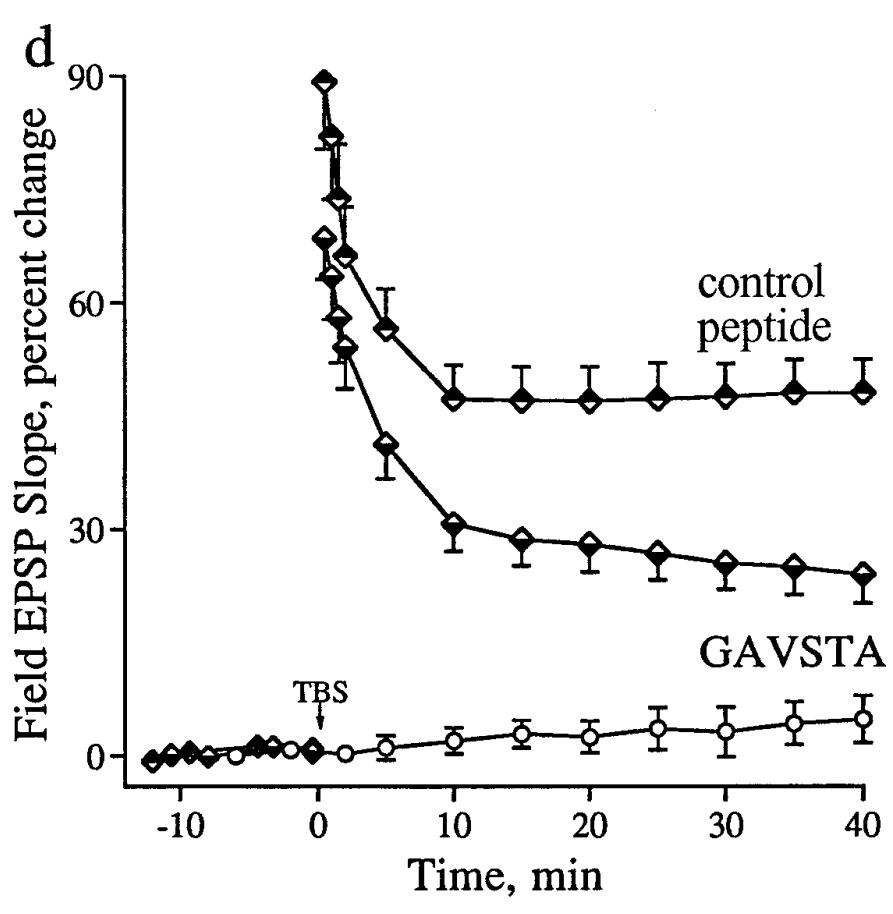

Figure 1. Effects of the integrin blocking peptide GAVSTA on LTP. $a-c$, Field EPSPs evoked by single stimulation pulses delivered to the Schaffer commissural projections were recorded in CA1 dendrites of hippocampal slices. Responses recorded at $2(a)$ and $40 \mathrm{~min}(b, c)$ after TBS are shown superimposed with baseline EPSPs recorded before TBS in slices preincubated with 1 mm GAVSTA $(a, b)$ or 2 mm control peptide ASG $(c)$ for 50-90 min (calibration: $1 \mathrm{mV}, 10 \mathrm{msec}$ ). $d$, The time course of potentiation in the presence of $0.8 \mathrm{~mm}$ GAVSTA $(n=16)$ or control peptide (2 mM ASG or $0.8 \mathrm{~mm}$ GRADSP; $n=16$ total) is shown with the results expressed as the percent change (group mean \pm SEM) from the average baseline field EPSP slope, measured during 15 min of recording before TBS (arrow). Open circles represent responses in GAVSTA-treated slices $(n=10)$ before administration of TBS.

$18 \pm 8 \%( \pm \mathrm{SD})$, responses in the control pathways remained stable (Fig. 2).

Compounds present during the application of TBS can influence the subsequent development of LTP in a variety of ways, 


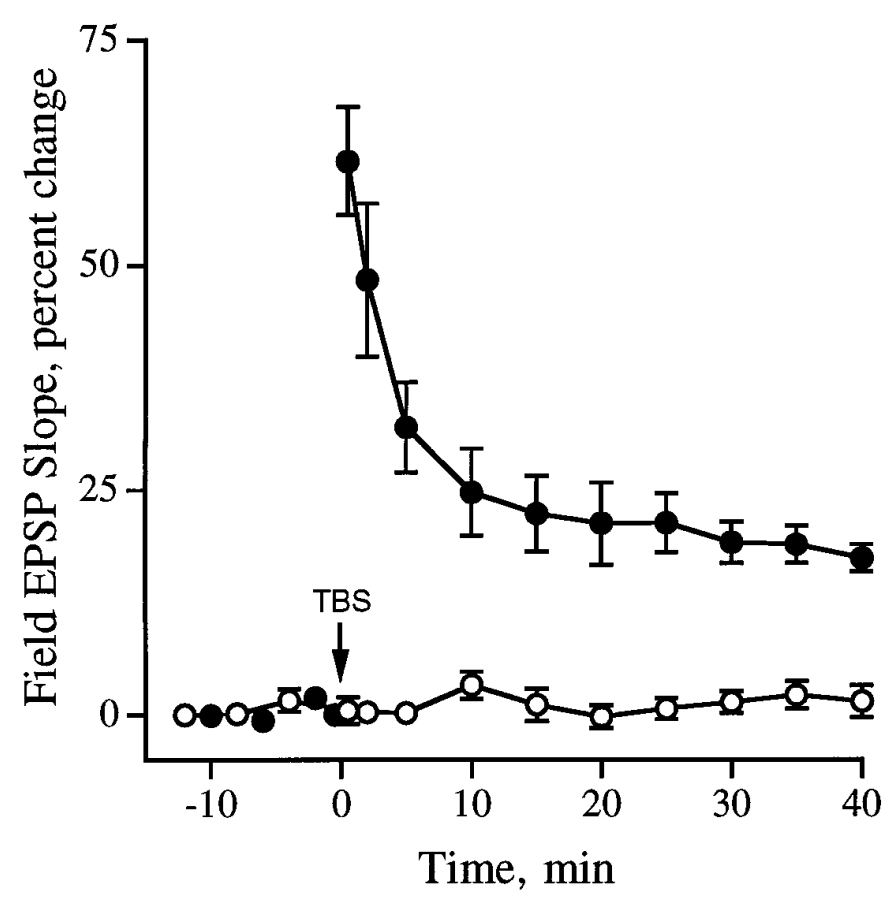

Figure 2. GAVSTA does not affect baseline synaptic transmission in nonpotentiated pathways. Four hippocampal slices were preincubated with $1 \mathrm{~mm}$ GAVSTA for 50-60 min. Subsequently, basal synaptic responses (open circles) were simultaneously recorded in one pathway while TBS was applied to the second pathway (solid circles) at time 0 (arrow). Results are expressed as the percent change from the average baseline field EPSP slope (group mean \pm SEM).

prominent among which are changes in the postsynaptic burst responses and their associated NMDA receptor-mediated currents (Larson and Lynch, 1988). To test the first of these, the sizes (i.e., areas) of the composite responses produced by individual theta bursts were measured in the two groups of slices. The first of the 10 burst responses was $50 \pm 8 \mathrm{mV} \cdot \mathrm{msec}( \pm \mathrm{SD})$ for the controls and $51 \pm 6 \mathrm{mV} \cdot \mathrm{msec}$ for the GAVSTA-treated slices. Bursts 2-10 were markedly facilitated with the effect being greater in the early than in later segments of the train (Fig. 3). This pattern of results is in agreement with that described previously (Arai et al., 1990b; del Cerro et al., 1990). It can also be seen from Figure 3 that there was only a slight difference between the two groups of slices; the small decrease in the experimental group as compared with controls was not significant. Thus, GAVSTA has little if any effect on the postsynaptic responses to the initial or subsequent bursts of afferent stimulation used in the TBS paradigm. The second possibility was ruled out by measuring the GAVSTA effects on synaptic responses mediated by activated NMDA receptors. In this study, hippocampal slices were perfused with a modified medium containing CNQX and low $\mathrm{Mg}^{2+}$, and the Schaffer collateral pathway was transected between fields CA3 and CA1 to prevent spontaneous bursting. As shown in Figure 4, infusion of the integrin antagonist GAVSTA had no influence on the NMDA receptor-mediated response component over a $75 \mathrm{~min}$ period. Infusion of AP5 was then used to confirm that the responses measured were exclusively mediated by NMDA receptors.

The above results suggest that integrin antagonists produce their effects by acting on some stage in the development of stable LTP that occurs after the induction of potentiation. To test this point further, studies were performed in which the antagonists

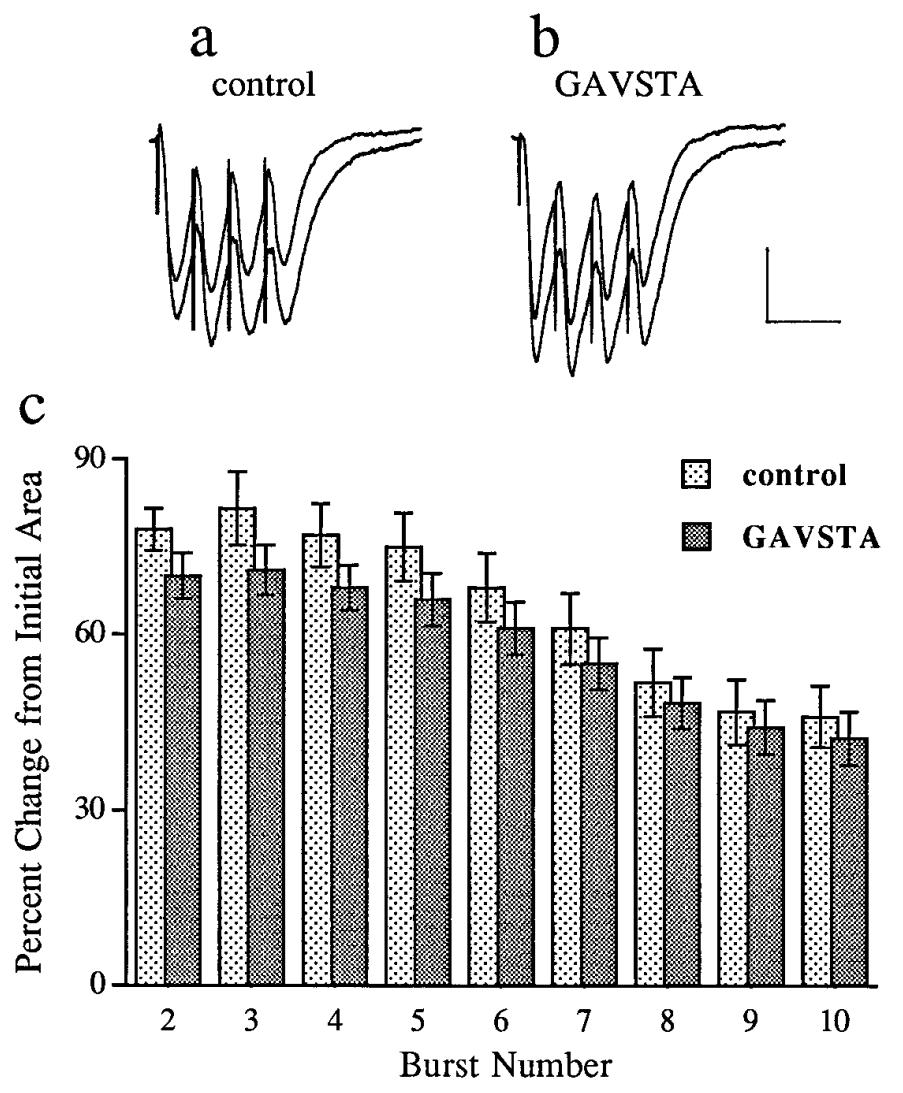

Figure 3. GAVSTA does not affect the postsynaptic responses to bursts of afferent stimulation used in the TBS induction paradigm of LTP. $a, b$, The initial burst response of a series of 10 is superimposed with the second facilitated response measured in slices preincubated with $2 \mathrm{~mm} \mathrm{ASG}(a)$ or $0.8 \mathrm{~mm}$ GAVSTA $(b)$ for $50-90 \mathrm{~min}$ (calibration: $1 \mathrm{mV}, 20 \mathrm{msec}$ ). $c$, The histogram shows the percent increase in burst area (mean \pm SEM) across the train of responses, as compared with the initial burst response, in control ( 2 mM ASG or $0.8 \mathrm{~mm}$ GRADSP; $n=14)$ and GAVSTA $(0.8 \mathrm{~mm}$; $n=14)$ slices.

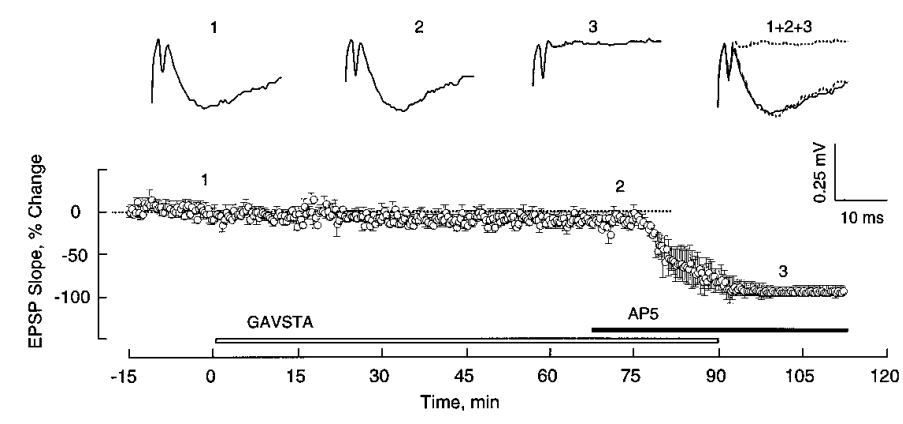

Figure 4. GAVSTA does not affect the NMDA receptor-mediated EPSP component. Responses elicited by single stimulation pulses delivered to the Schaffer commissural projections were recorded in the presence of 20 $\mu \mathrm{M}$ CNQX and low $\mathrm{Mg}^{2+}(50-100 \mu \mathrm{M})$. The plotted data are group means $( \pm$ SEM) represented as the percent change from the average baseline slope measured $15 \mathrm{~min}$ before the start of constant infusion of $1 \mathrm{~mm}$ $\operatorname{GAVSTA}(n=7)$. Subsequent infusion of the NMDA receptor antagonist AP5 $(200 \mu \mathrm{M})$ was initiated where indicated. Typical responses recorded at the times indicated above the graph are shown.

were infused into slices after TBS and the emergence of enhanced field EPSPs. GRGDSP and RGDS, peptides that are more potent and more commonly used in integrin research than GAVSTA, were used in these experiments to selectively target the recogni- 

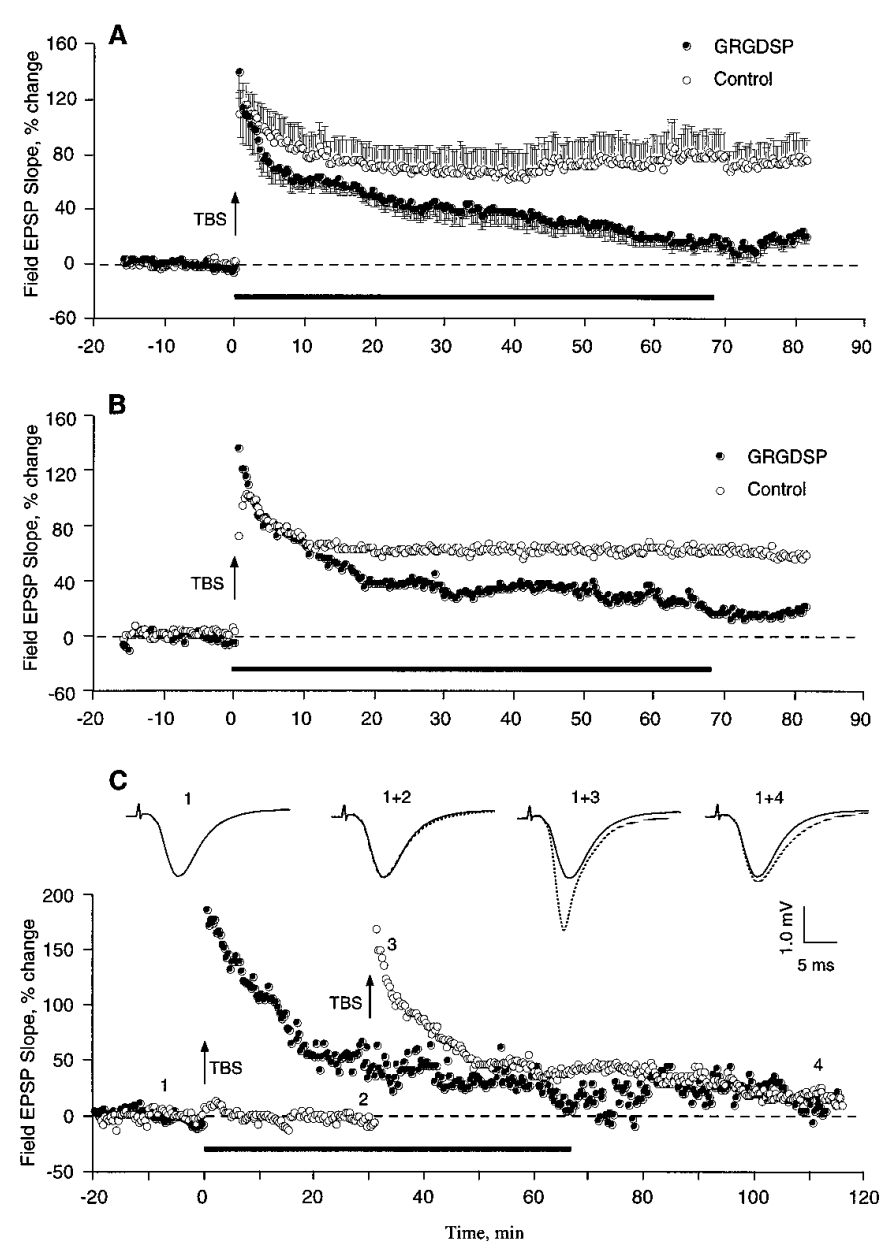

Figure 5. Effect of an integrin antagonist applied immediately after the induction of LTP. $A$ summarizes results (mean \pm SEM) for a group of control $(n=7)$ and GRGDSP-treated $(n=10)$ slices, whereas $B$ illustrates individual experiments. Infusion of GRGDSP (0.5 mM; see bar) was begun within 1 min of the conclusion of a train of 10 theta bursts (TBS) applied to the Schaffer commissural fibers. $C$ shows an example in which baseline responses were simultaneously recorded from a second pathway while TBS was delivered to another. Baseline EPSPs recorded before and after $30 \mathrm{~min}$ of GRGDSP infusion (traces 1,2) are shown, as are potentiated responses measured 2 min (trace 3 ) and $80 \mathrm{~min}$ (trace 4) after TBS (trace 1 is the nondotted record).

tion site of RGDS-binding matrix receptors. Figure 5 summarizes group results $(A)$ and individual experiments $(B, C)$ obtained with GRGDSP infusions beginning immediately after the induction of LTP. In control slices given TBS with no additional treatment, potentiation decreased for $10-15 \mathrm{~min}$ after induction but then remained stable for the subsequent $60-70 \mathrm{~min}$ of testing. Experimental slices ( $0.5 \mathrm{~mm}$ GRGDSP, $n=10)$ were indistinguishable from controls during the initial post-TBS period but differed markedly in that the potentiation continued to diminish throughout the remaining hour of testing at a rate of $15-20 \% / \mathrm{hr}$. In two experiments in which responses were simultaneously recorded in a control pathway while potentiation was induced in a separate pathway, the baseline remained stable during the time GRGDSP caused an $\sim 45 \%$ reduction in the degree of potentiation (Fig. $5 C$ ). The integrin antagonist also did not affect baseline synaptic transmission measured over a 55 min infusion period followed by a 55 min period of washout (Fig. 6, see also Figs. 1, 2). RGDS peptides were shown previously to produce no evident changes in

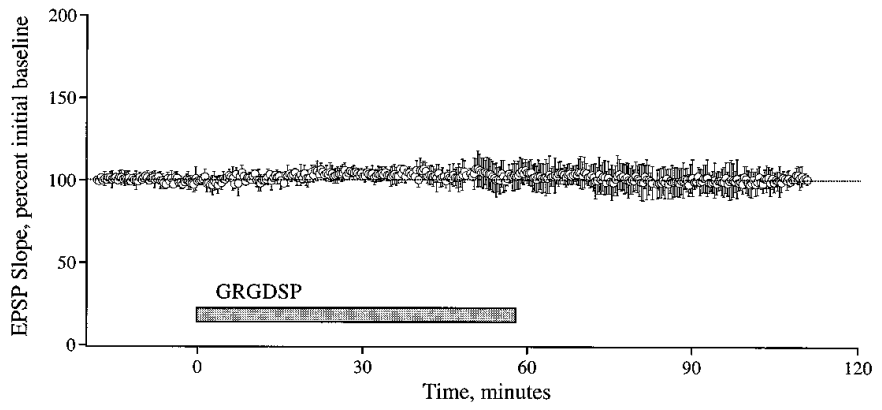

Figure 6. Basal synaptic transmission is unaffected by GRGDSP. Field EPSPs were elicited by single stimulation pulses delivered to the Schaffer commissurals of four slices, and the initial slope was measured. The plotted data are group means $( \pm$ SD) represented as the percent of the initial baseline established over an $18 \mathrm{~min}$ period before a $55 \mathrm{~min}$ infusion of GRGDSP $(0.5 \mathrm{~mm})$. Responses were continually recorded during washout of the peptide.

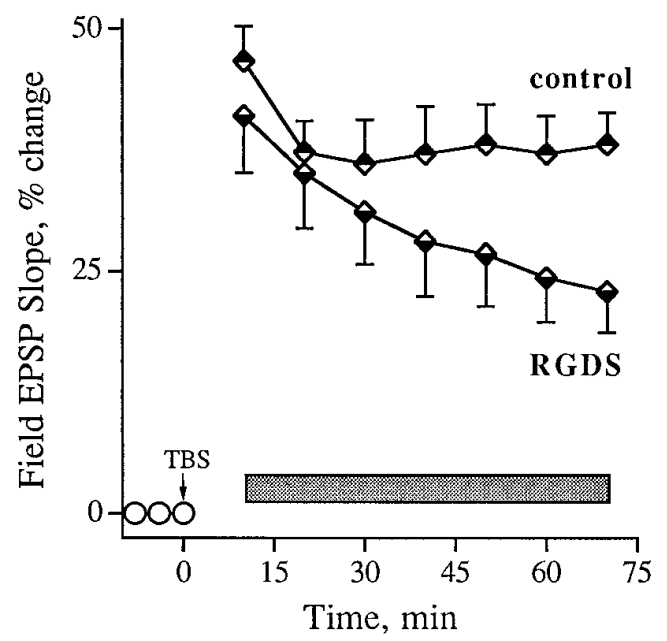

Figure 7. Effect of RGDS peptides on previously established LTP. Field EPSPs were recorded in CA1, and LTP was induced at time 0 with TBS (arrow). RGDS (1 mM RGDS or $0.2 \mathrm{~mm}$ GRGDSP; $n=13$ total) or control (vehicle or $6 \mathrm{~mm}$ tetraglycine; $n=17$ total) peptides were infused into the interface chamber $10 \mathrm{~min}$ after TBS was administered to a slice (bar). Group means ( \pm SEM) of the change in baseline EPSP initial slope (circles) are shown. Two-tailed $t$ test between the two groups of slices at 70 min after induction: $p<0.01$.

the size or waveform of synaptic responses in hippocampal slices (Staubli et al., 1990; Xiao et al., 1991).

As shown in Figure 7, a decay of potentiation similar to the above results was obtained with infusions of RGDS peptides beginning $10 \mathrm{~min}$ after the train of theta bursts. The potentiation profile in control slices treated with no peptide or $6 \mathrm{~mm}$ tetraglycine was nondecremental and had a small positive slope between 25 and 70 min post-TBS $(r=0.76)$. Slices infused with integrin antagonist, on the other hand, exhibited a potentiation that closely matched the control effect at $20 \mathrm{~min}$ post-TBS but then failed to stabilize; i.e., it decayed steadily between 25 and $70 \mathrm{~min}$ at a rate of $12 \pm 1 \% / \mathrm{hr}(r=-0.99)$. Both GRGDSP and RGDS were effective when applied $10 \mathrm{~min}$ after TBS. The degree of potentiation remaining $70 \mathrm{~min}$ after induction was $38 \pm 14 \%$ for the controls and $23 \pm 15 \%$ for the experimental group $(p<0.01)$. Interestingly, a comparable rate of decay $(10 \pm 2 \% / \mathrm{hr})$ was obtained when hippocampal slices were pretreated for 60-90 min with RGDS-containing peptides, as determined from data re- 


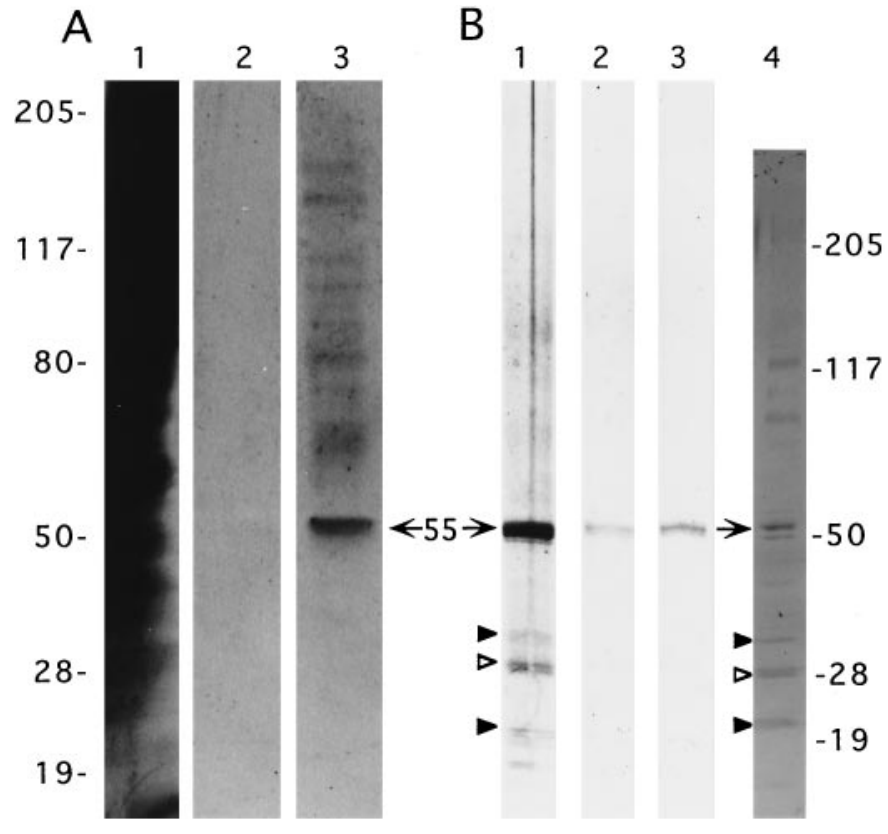

Figure 8. Affinity purification of RGDS-binding proteins. Solubilized SPMs isolated from whole brain (A1-3) and hippocampus (B1-3) were applied to separate columns containing immobilized GRGDSPK, as described in Materials and Methods. Silver-stained electrophoresis samples consisted of concentrated fraction aliquots collected from column volumes containing nonbound material $(A 1)$, the fifth wash $(A 2)$, and GRGDSP eluant (A3). The column loaded with hippocampal SPMs was washed thoroughly, and fractions were collected containing GAVSTA eluant (B1), the wash after the GAVSTA elution (B2), and the subsequent GRGDSP eluant (B3). Lane 4 contains $50 \mu \mathrm{g}$ cortical SPM protein and was immunoblotted with anti- $\beta_{1}$ antibodies. The electrophoretic positions of molecular weight standards (in kilodaltons) are shown on the left for lanes A1-3 and on the right for lanes B1-4. Arrows, $55 \mathrm{kDa}$ synaptegrin-1; arrowheads, 20, 27, and $30 \mathrm{kDa}$ RGDS-binding proteins (see text).

ported by Xiao et al. (1991). Pretreatment with the antagonist GAVSTA also caused a similar decay rate of $11 \pm 1 \% / \mathrm{hr}$ starting 25 min after TBS (see Fig. 1d). As was the case for control slices in Figure 7, the controls in Figure $1 d$ exhibited nondecremental LTP during the latter part of the test period. It appears, then, that blocking integrin adhesion sites before or after LTP induction produces nearly equal rates of decline in the magnitude of potentiation.

In an attempt to identify targets of the integrin antagonists used in the above physiological studies, detergent-solubilized SPMs were applied to a GRGDSPK-sepharose column. The affinity column was subsequently washed without and then with antagonist added to the column buffer, and the eluted material was subjected to electrophoretic separation and silver staining. GRGDSP displaced a $55 \mathrm{kDa}$ doublet from a column loaded with whole-brain SPMs, together with what appeared to be lesser quantities of higher-molecular-weight proteins (Fig. 8A, lane 3). The eluted $55 \mathrm{kDa}$ protein exhibited only trace labeling on blots stained with antibodies to the $\alpha_{5} \beta_{1}$ integrin (a fibronectin receptor), whereas the larger proteins displaced by the integrin antagonist were not detected. Intense and selective anti- $\alpha_{5} \beta_{1}$ immunostaining was shown previously for a $55 \mathrm{kDa}$ doublet species purified from SPMs by fibronectin-affinity chromatography (Bahr and Lynch, 1992). It is not surprising that a lower yield of the 55 $\mathrm{kDa}$ protein was obtained from the GRGDSPK column as compared with immobilized fibronectin, because other matrix recep- tors have a 3000-fold lower affinity for the short peptide than for the native matrix protein (see Pierschbacher and Ruoslahti, 1984). The eluted $55 \mathrm{kDa}$ doublet and the three to four bands of 70-140 $\mathrm{kDa}$ did, in fact, comigrate with SPM proteins detected by the integrin antibodies (Fig. 8B, lane 4); the $120 \mathrm{kDa}$ antigen is of particular interest, because it has the approximate weight of the $\beta_{1}$ integrin subunit from rat brain (see Balzac et al., 1993; Grooms et al., 1993). The present results indicate that a $55 \mathrm{kDa}$ matrix receptor, for which we suggest the name "synaptegrin-1" (formerly F55), recognizes the RGDS sequence and, hence, may participate in the stabilization of LTP.

Results obtained with solubilized hippocampal SPMs applied to a fresh GRGDSP-affinity column are shown in Figure $8 B$. After extensive column washes, the first elution volume contained GAVSTA as the elutant to test whether the two structurally dissimilar peptides used in the physiological experiments influence a common matrix receptor. Consequently, a substantial quantity of the $55 \mathrm{kDa}$ synaptegrin-1, as well as lesser amounts of smaller proteins of $\sim 20,27$, and $30 \mathrm{kDa}$, was eluted (lane 1). A subsequent elution with GRGDSP displaced more synaptegrin-1 and a slight amount of the $27 \mathrm{kDa}$ doublet (lane 3). Thus, these results identify at least two proteins that are targeted by different types of integrin antagonists. Also, in contrast with the pattern of eluted bands in the experiment using whole-brain SPMs (Fig. 8A), neither GAVSTA nor GRGDSP displaced sizable amounts of hippocampal proteins $>55 \mathrm{kDa}$ in size. This suggests that hippocampal synaptic membranes, while possessing substantial quantities of synaptegrin-1 as found in whole-brain SPMs, are distinctive with regard to their composition of RGDS-binding proteins. The eluted bands of $20-30 \mathrm{kDa}$ in Figure $8 B$ correspond to antigens recognized by affinity-purified antibodies to the $\beta_{1}$ protein (lanes 1,4 , arrowheads). The $\sim 27 \mathrm{kDa}$ band (open arrowhead) is of particular interest, because it is more abundant than the other small polypeptides in the eluted material and has recently been identified as an RGDS-dependent fibrinogen-binding protein (Bahr et al., 1997). It may correspond to a $27 \mathrm{kDa}$ brainspecific protein found previously to be concentrated in synaptic membranes and recognized by certain integrin antibodies (Bahr et al., 1991b). The lower yield from the affinity column for the fibrinogen-binding $27 \mathrm{kDa}$ species versus synaptegrin-1 likely stems from the difference between the integrin recognition sequence within fibrinogen (Asn-Arg-Gly-Asp-Ser-Thr; i.e., NRGDST) and the GRGDSP domain in fibronectin (Pierschbacher and Ruoslahti, 1984).

The concentration of synaptegrin-1 was not increased in hippocampal SPMs incubated with calcium for $30 \mathrm{~min}$ at $37^{\circ} \mathrm{C}$ relative to samples either coincubated at the same temperature in the presence of the protease inhibitor leupeptin or at $0^{\circ} \mathrm{C}$ with no additions (data not shown). Synaptegrin-1 thus is not likely to be a cleavage product of a larger protein. Actually, the immunostaining of the $55 \mathrm{kDa}$ antigen decreased in intensity because of the activation of leupeptin-sensitive, $\mathrm{Ca}^{2+}$-dependent proteases, as is the case for conventional integrin subunits (Bahr et al., 1997).

In light of the disruptive action of GAVSTA and GRGDSP on synaptic modulation, it was deemed important to estimate the degree to which targets of the dissimilar antagonists are localized to brain synapses. Accordingly, tests were carried out to determine whether synaptegrin-1 and other RGDS-binding proteins comigrate with known synaptic markers during subcellular fractionation. Fresh P2 preparations from rat forebrain were applied to Percoll-density gradients to separate synaptosomes from mitochondria, myelin, and cell fragments (Fig. 9). Membranous ma- 


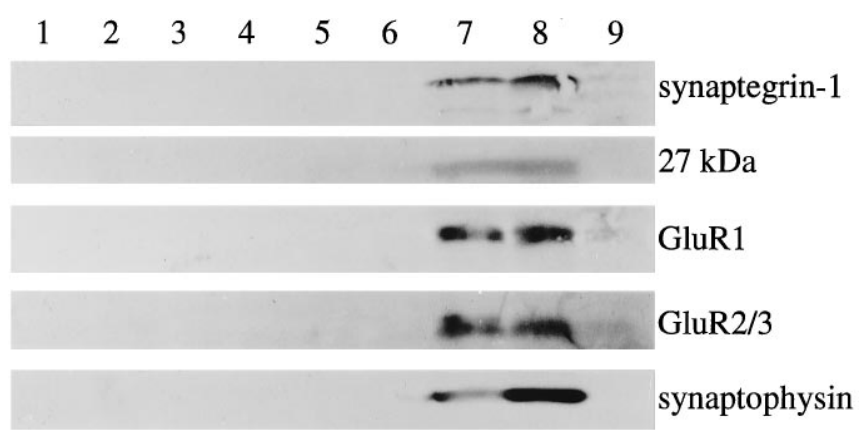

Figure 9. Comigration of RGDS-binding proteins and synaptic markers across density gradients. Fresh forebrain P2 suspensions were applied to 3-25\% Percoll gradients to isolate synaptosomes, as described in Materials and Methods. The interfacial zones of the gradients were separated, washed by centrifugation, and hyposmotically treated. Aliquots of the soluble fraction from interfacial zones $2-5$ were concentrated and prepared for immunoblotting (lanes 1-4, respectively); lysed membranes from zones 1-5 (lanes 5-9; $70 \mu \mathrm{g}$ protein each) were also immunoblotted. The following antibodies were used: anti- $\beta_{1}$ (labeled $55 \mathrm{kDa}$ synaptegrin1 ), anti- $\alpha_{\mathrm{v}} \beta_{3}$ (labeled a $27 \mathrm{kDa}$ antigen), anti-GluR1, anti-GluR2/3, and anti-synaptophysin.

terial was isolated from the collected fractions by lysis and centrifugation (lanes 5-9; equal protein in each) and analyzed separately from corresponding supernatants (lanes 1-4). As shown, synaptegrin-1 and the $27 \mathrm{kDa}$ matrix receptor comigrated with the presynaptic protein synaptophysin and with the GluR1 and GluR2/3 subunits of AMPA-type glutamate receptors (lanes $7,8)$. None of the five antigens were evident at the top of the gradients (lanes 5,6); however, a number of molecular species were found concentrated in these fractions, including a highly sulfated proteoglycan of $\sim 400 \mathrm{kDa}$ (data not shown). In addition, little or no synaptegrin (or synaptic marker) was detected in the bottom fraction of the gradients (lane 9), which is known to contain primarily mitochondrial membranes (Dunkley et al., 1986). Similar density gradients verified that mitochondria migrate to high-density fractions, whereas myelin basic protein and extracellular matrix material remain in the top fractions of low density. Figure 9 also indicates that the synaptegrin adhesion molecules were restricted to membrane pellets, as were synaptic proteins, whereas sulfated proteoglycans labeled by two different antibodies were concentrated in the soluble fractions (lanes 1-4).

Finally, relative concentrations of synaptegrin-1 in SPMs from different brain regions were estimated from immunoblots to be as follows: hippocampus $\gg$ olfactory bulb $>$ cerebellum $\approx$ striatumrich tissue $>$ neocortex $\geq$ thalamus-rich tissue $>$ brainstem (data not shown). This distribution is quite different from that of the 27 $\mathrm{kDa} \beta_{1}$-like polypeptide. In particular, the $27 \mathrm{kDa}$ antigen was shown to be less abundant in hippocampal and olfactory bulb SPMs as compared with synaptic fractions from cerebellar and neocortical tissue (Bahr et al., 1997).

\section{DISCUSSION}

The above results indicate that a small peptide that mimics the binding domain of a subclass of integrins blocks the stabilization of LTP without detectably affecting baseline synaptic physiology, the current produced by NMDA receptors, the burst responses that trigger the potentiation effect, or the initial facilitation of responses that follows the bursts. These findings are complementary to those showing that RGDS peptides, which compete with the matrix protein domain recognized by many integrins, also selectively disrupt the formation of stable LTP (Staubli et al.,
1990; Xiao et al., 1991). Taken together, the comparable results obtained with dissimilar peptides constitute evidence that integrin-like matrix recognition events participate in the conversion of potentiation into a nondecremental state.

Experiments in which integrin antagonists were infused after LTP induction stimuli had been delivered indicate that the integrin-binding events either occur over an extended period of time or are a late step in a sequence leading to stabilization. There is precedent for the latter possibility. Blood platelets exposed to an appropriate stimulus undergo morphological transformations that are reversible until activation of latent RGDS-binding integrins and their subsequent interaction with matrix components have occurred (Marguerie et al., 1980; Siess, 1989; Negrescu et al., 1995). Similar effects are found in other types of cells (Matsuyama et al., 1989; Ingber, 1991; Chang et al., 1995) including neurons (see Arregui et al., 1994). Possibly, then, unmasking or addition of latent integrin-like receptors at potentiated synapses requires many min, and any induced morphological changes remain reversible until this is accomplished. There is now considerable evidence that LTP itself, while developing within 10 to $30 \mathrm{sec}$ (see Hanse and Gustafsson, 1994), is susceptible to full reversal for an extended period after its induction. Specifically, trains of low frequency stimulation applied min after the induction of robust potentiation were found to selectively reverse LTP in acute, anesthetized animals (Barrionuevo et al., 1980). This was confirmed in rats with chronically implanted electrodes, a preparation with which it was possible to show that LTP did not spontaneously reappear after the reversal (Staubli and Lynch, 1990). LTP reversal has also been obtained in hippocampal slices using brief hypoxic events (Arai et al., 1990b), infusions of adenosine (Arai et al., 1990a), and low frequency synaptic stimulation (Fujii et al., 1991; Mulkey and Malenka, 1992; Larson et al., 1993; Staubli and Chun, 1996). In each of these cases, the experimental manipulation was effective only if applied shortly after induction; the duration of the "vulnerable" period has not been firmly established, but recent work indicates that it can last for at least 15-30 min (Staubli and Chun, 1996; also see Bittar and Muller, 1993; Barr et al., 1995). These observations, together with the present results, indicate that the stabilization of LTP is a protracted process likely to involve an extended series of steps, some of which involve specific adhesion molecules.

The LTP blocking effects obtained with integrin antagonists differ from those found with agents that interfere with cell surface adhesion receptors belonging to the immunoglobulin superfamily (i.e., NCAM and L1). Dissociation of the complex between L1 and NCAM produced a marked decrease in the initial potentiation 1-2 min after delivery of LTP induction stimuli (Lüthi et al., 1994; Rønn et al., 1995; see also Muller et al., 1996), and infusion of the dissociating agents 10 min after induction had no effect on already established LTP (Lüthi et al., 1994). This suggests that NCAMs are involved in early $(<10 \mathrm{~min}$ after induction, rather than late or delayed, processes triggered by the initiation of LTP; these early processes may include disassembly and/or early development phases controlling configurational changes in the synaptic architecture (see Covault et al., 1991; Sheppard et al., 1991). Integrin-type matrix receptors, on the other hand, are likely involved in the later stabilization phase(s) of LTP as supported by the present report. Latent matrix receptors activated to form transmembrane linkages (Matsuyama et al., 1989; Shimizu et al., 1990; Du et al., 1991; Tanaka et al., 1992) could function long after LTP induction to govern new membrane configurations and stably control compartmentation of glutamatergic regulatory pro- 
teins (Greengard et al., 1991; Wang et al., 1991; Rosenmund and Westbrook, 1993; Rosenmund et al., 1994; Yakel et al., 1995; see also Sheng, 1996). Thus, distinct phases of LTP consolidation are distinguished by separate classes of adhesion molecules. According to this idea, the two types of adhesion molecules constitute a system that first stabilizes a potentiated state of excitatory synapses and then establishes an appropriate environment for maintaining the new functional state. Note that the stabilization phase occurs between induction and the end of the "vulnerable" period described above. Beyond this period, LTP reversing stimuli are no longer effective and no active processes appear to be involved in the expression of the potentiated state (see Larson and Vanderklish, 1997). One plausible scenario is that the synaptic structure has been redefined by strategically localized focal adhesions, and this new structure is maintained by normal cellular processes.

Experiments using affinity chromatography confirmed that hippocampal synapses are enriched in a small set of proteins that bind the RGDS sequence and hence are likely to be functionally disrupted by the integrin antagonists used to prevent LTP stabilization. One of these proteins with a molecular weight of $55 \mathrm{kDa}$ is particularly well suited to serve as a synaptic, integrin-like receptor (i.e., a synaptegrin), because it (1) binds to a matrix protein in a selective manner, (2) recognizes the RGDS sequence, (3) is labeled by antibodies to specific integrin receptors and subunits, (4) does not appear to be found outside the brain, (5) is greatly enriched in synaptic membrane fractions, and (6) comigrates with synaptic marker proteins during the isolation of synaptosomes. This matrix receptor, referred to here as synaptegrin-1, is substantially smaller than the subunits of known integrins, thus raising the possibility that it is a cleavage product of perhaps the $\beta_{1}$ integrin subunit. However, this was not evident in proteolyzed samples and, moreover, would require the pertinent protease to be (1) extremely active (the $\beta_{1}$ protein does not co-occur in sizable concentrations with synaptegrin-1 in any tissue fraction examined thus far), (2) resistant to a variety of broadspectrum inhibitors (such compounds are added to all dissection and fractionation buffers), and (3) brain-specific $\left[\beta_{1}\right.$ is found throughout the body (Balzac et al., 1993) but synaptegrin-1 is not (Bahr and Lynch, 1992)]. The size of the synaptegrin adhesion molecule is also similar to that of the major species phosphorylated in cultured neuronal cells in response to anandamide, an agent that regulates a focal adhesion kinase found concentrated in hippocampal neurons (Derkinderen et al., 1996; see also Burgaya et al., 1995). Anandamide is an endogenous ligand for central cannabinoid receptors, is released after neuronal depolarization, and initiates a signal transduction pathway implicated in cytoskeletal modulation. Given the characteristics of synaptegrin-1, it is likely that the matrix receptor is an integrin variant with properties that are specialized for functional regulation of synapses.

\section{REFERENCES}

Akiyama SK, Yamada SS, Chen WT, Yamada KM (1989) Analysis of fibronectin receptor function with monoclonal antibodies: roles in cell adhesion, migration, matrix assembly, and cytoskeletal organization. J Cell Biol 109:863-875.

Albelda SM, Buck CA (1990) Integrins and other cell adhesion molecules. FASEB J 4:2868-2880.

Arai A, Kessler M, Lynch G (1990a) The effects of adenosine on the development of long-term potentiation. Neurosci Lett 119:41-44.

Arai A, Larson J, Lynch G (1990b) Anoxia reveals a vulnerable period in the development of long-term potentiation. Brain Res 511:353-357.

Arregui CO, Carbonetto S, McKerracher L (1994) Characterization of neural cell adhesion sites: point contacts are the sites of interaction between integrins and the cytoskeleton in PC12 cells. J Neuroscience 14:6967-6977.

Bahr BA, Lynch G (1992) Purification of an Arg-Gly-Asp selective matrix receptor from brain synaptic plasma membranes. Biochem $\mathrm{J}$ 281:137-142.

Bahr BA, Sheppard A, Lynch G (1991a) Fibronectin binding by brain synaptosomal membranes may not involve conventional integrins. NeuroReport 2:13-16.

Bahr BA, Sheppard A, Vanderklish PW, Bakus BL, Capaldi D, Lynch G (1991b) Antibodies to the $\alpha_{\mathrm{v}} \beta_{3}$ integrin label a protein concentrated in brain synaptosomal membrane. NeuroReport 2:321-324.

Bahr BA, Capaldi D, Rosario R, Esteban ET, Lynch G (1997) A 27 kDa matrix receptor from rat brain synaptosomes: selective recognition of the Arg-Gly-Asp-Ser domain and resistance to calcium-dependent proteolysis, in press.

Balzac F, Belkin AM, Koteliansky VE, Balabanov YV, Altruda F, Silengo L, Tarone G (1993) Expression and functional analysis of a cytoplasmic domain variant of the $\beta 1$ integrin subunit. J Cell Biol 121:171-178.

Barr DS, Lambert NA, Hoyt KL, Moore SD, Wilson WA (1995) Induction and reversal of long-term potentiation by low- and high-intensity theta pattern stimulation. J Neurosci 15:5402-5410.

Barrionuevo G, Schottler F, Lynch G (1980) The effects of repetitive low frequency stimulation on control and "potentiated" synaptic responses in the hippocampus. Life Sci 27:2385-2391.

Bittar P, Muller D (1993) Time-dependent reversal of long-term potentiation by brief cooling shocks in rat hippocampal slices. Brain Res 620:181-188.

Bliss TVP, Gardner-Medwin AR (1973) Long-lasting potentiation of synaptic transmission in the dentate area of the unanesthetized rabbit following stimulation of the perforant path. J Physiol (Lond) 232:357-374.

Bliss TVP, Lomo T (1973) Long-lasting potentiation of synaptic transmission in the dentate area of the anaesthetized rabbit following stimulation of the perforant path. J Physiol (Lond) 232:334-356.

Brentani RR, Ribeiro SF, Potocnjak P, Pasqualini R, Lopes JD, Nakaie CR (1988) Characterization of the cellular receptor for fibronectin through a hydropathic complementary approach. Proc Natl Acad Sci USA 85:364-367.

Buchs P-A, Muller D (1996) Induction of long-term potentiation is associated with major ultrastructural changes of activated synapses. Proc Natl Acad Sci USA 93:8040-8045.

Burgaya F, Menegon A, Menegoz M, Valtorta F, Girault JA (1995) Focal adhesion kinase in rat central nervous system. Eur J Neurosci 7:1810-1821.

Burridge K, Fath K, Kelly T, Nuckolls G, Turner C (1988) Focal adhesions: transmembrane junctions between the extracellular matrix and the cytoskeleton. Annu Rev Cell Biol 4:478-525.

Chang F-LF, Greenough WT (1984) Transient and enduring morphological correlates of synaptic activity and efficacy change in the rat hippocampal slice. Brain Res 309:35-46.

Chang MC, Jeng JH, Cheong TC, Huang TF (1995) The morphologic change of endothelial cells by ancrod-generated fibrin is triggered by $\alpha_{\mathrm{v}} \beta_{3}$ integrin binding and the subsequent activation of a G-protein coupled phospholipase C. Biochim Biophys Acta 1269:115-121.

Clark EA, Brugge JS (1995) Integrins and signal transduction pathways: the road taken. Science 268:233-239.

Covault J, Liu Q, El-Deeb S (1991) Calcium-activated proteolysis of intracellular domains in the cell adhesion molecules NCAM and N-cadherin. Mol Brain Res 11:11-16.

del Cerro S, Larson J, Oliver MW, Lynch G (1990) Development of hippocampal long-term potentiation is reduced by recently introduced calpain inhibitors. Brain Res 530:91-95.

Derkinderen P, Toutant M, Burgaya F, Le Bert M, Siciliano JC, de Franciscis V, Gelman M, Girault J-A (1996) Regulation of a neuronal form of focal adhesion kinase by anandamide. Science 273:1719-1722.

Desmond NL, Levy WB (1983) Synaptic correlates of associative potentiation/depression: an ultrastructural study in the hippocampus. Brain Res 265:21-30.

Du XP, Plow EF, Frelinger AL, O’Toole TE, Loftus JC, Ginsberg MH (1991) Ligands "activate" integrin $\alpha_{\text {IIb }} \beta_{3}$ (platelet GPIIb-IIIa). Cell 65:409-416.

Dunkley PR, Jarvie PE, Heath JW, Kidd GJ, Rostas JAP (1986) A rapid method for isolation of synaptosomes on percoll gradients. Brain Res 372:115-129. 
Einheber S, Schnapp LM, Salzer JL, Cappiello ZB, Milner TA (1996) Regional and ultrastructural distribution of the $\alpha_{8}$ integrin subunit in developing and adult rat brain suggests a role in synaptic function. J Comp Neurol 370:105-134.

Fogerty FJ, Akiyama SK, Yamada KM, Mosher DF (1990) Inhibition of binding of fibronectin to matrix assembly sites by anti-integrin (alpha 5 beta 1) antibodies. J Cell Biol 111:699-708.

Fujii S, Saito K, Miyakawa H, Ito K, Kato H (1991) Reversal of longterm potentiation (depotentiation) induced by tetanus stimulation of the input to CA1 neurons of guinea pig hippocampal slices. Brain Res 555:112-122.

Geinisman Y, de Toledo-Morrell L, Morrell F, Heller RE, Rossi M, Parshall RF (1993) Structural synaptic correlates of long-term potentiation: formation of axospinous synapses with multiple, completely partitioned transmission zones. Hippocampus 3:435-445.

Greengard P, Jen J, Nairn AC, Stevens CF (1991) Enhancement of the glutamate response by cAMP-dependent protein kinase in hippocampal neurons. Science 253:1135-1138.

Grooms SY, Terracio L, Jones LS (1993) Anatomical localization of $\beta 1$ integrin-like immunoreactivity in rat brain. Exp Neurol 122:253-259.

Gustafsson B, Asztely F, Hanse E, Wigström H (1989) Onset characteristics of long-term potentiation in the guinea-pig hippocampal CA1 region in vitro. Eur J Neurosci 1:382-394.

Hanse E, Gustafsson B (1994) Onset and stabilization of NMDA receptor-dependent hippocampal long-term potentiation. Neurosci Res 20:15-25.

Horwitz A, Duggan E, Buck C, Beckerle MC, Burridge K (1986) Interaction of plasma membrane fibronectin receptor with talin: a transmembrane linkage. Nature 320:531-533.

Hynes RO (1992) Integrins: versatility, modulation, and signaling in cell adhesion. Cell 69:11-25.

Ingber D (1991) Extracellular matrix and cell shape: potential control points for inhibition of angiogenesis. J Cell Biochem 47:236-241.

Jones LS (1996) Integrins: possible functions in the adult CNS. Trends Neurosci 19:68-72.

Jones LS, Grooms S (1995) Localization of the $\alpha_{5}$ integrin-like immunofluorescence in the adult rat hippocampus. Soc Neurosci Abstr 21:1313.

Larson J, Lynch G (1988) Role of $N$-methyl-D-aspartate receptors in the induction of synaptic potentiation by burst stimulation patterned after the hippocampal theta rhythm. Brain Res 441:111-118.

Larson J, Vanderklish PW (1997) Involvement of AMPA receptors in LTP mechanisms and memory. In: Long-term potentiation, Vol 3 (Baudry M, Davis JL, eds), pp 73-103. Cambridge: MIT.

Larson J, Wong D, Lynch G (1986) Patterned stimulation at the theta frequency is optimal for induction of hippocampal long-term potentiation. Brain Res 368:347-350.

Larson J, Xiao P, Lynch G (1993) Reversal of LTP by theta frequency stimulation. Brain Res 600:97-102.

Lee K, Oliver M, Schottler F, Creager R, Lynch G (1979) Ultrastructural effects of repetitive synaptic stimulation in the hippocampal slice preparation: a preliminary report. Exp Neurol 65:478-480.

Lee K, Schottler F, Oliver M, Lynch G (1980) Brief bursts of highfrequency stimulation produce two types of structural changes in rat hippocampus. J Neurophysiol 44:247-258.

Lüthi A, Parent J-P, Figurov D, Muller D, Schachner M (1994) Hippocampal long-term potentiation and neural cell adhesion molecules L1 and NCAM. Nature 372:777-779.

Marguerie GA, Edgington TS, Plow EF (1980) Interaction of fibrinogen with its platelet receptor as part of a multistep reaction in ADP-induced platelet aggregation. J Biol Chem 255:154-161.

Matsuyama T, Yamada A, Kay J, Yamada KM, Akiyama SK, Schlossman SF, Morimoto C (1989) Activation of CD4 cells by fibronectin and anti-CD3 antibody. A synergistic effect mediated by the VLA-5 fibronectin receptor complex. J Exp Med 170:1133-1148.

Mulkey RM, Malenka RC (1992) Mechanisms underlying induction of homosynaptic long-term depression in area CA1 of the hippocampus. Neuron 9:967-975.

Muller D, Wang C, Skibo G, Toni N, Cremer H, Calaora V, Rougon G, Kiss JZ (1996) PSA-NCAM is required for activity-induced synaptic plasticity. Neuron 17:413-422.

Negrescu EV, de Quintana KL, Siess W (1995) Platelet shape change induced by thrombin receptor activation. Rapid stimulation of tyrosine phosphorylation of novel protein substrates through an integrin- and $\mathrm{Ca} 2+$-independent mechanism. J Biol Chem 270:1057-1061.

Nosten-Bertrand M, Errington ML, Murphy KPSJ, Tokugawa Y, Barboni E, Kozlova E, Michalovich D, Morris RGM, Silva J, Stewart CL, Bliss TVP, Morris RJ (1996) Normal spatial learning despite regional inhibition of LTP in mice lacking Thy-1. Nature 379:826-829.

Otey CA, Pavalko FM, Burridge K (1990) An interaction between $\alpha$-actinin and the $\beta 1$ integrin subunit in vitro. J Cell Biol 111:721-729.

Pasqualini R, Chamone DF, Brentani RR (1989) Determination of the putative binding site for fibronectin on platelet glycoprotein IIb-IIIa complex through a hydropathic complementarity approach. J Biol Chem 264:14566-14570.

Pierschbacher MD, Ruoslahti E (1984) Cell attachment activity of fibronectin can be duplicated by small synthetic fragments of the molecule. Nature 309:30-33.

Persohn E, Pollerberg E, Schachner M (1989) Immunoelectronmicroscopic localization of the $180 \mathrm{kDa}$ component of the neural cell adhesion molecule NCAM in postsynaptic membranes. J Comp Neurol 288:92-100.

Pytela R, Pierschbacher MD, Ruoslahti E (1985) Identification and isolation of a $140 \mathrm{kd}$ cell surface glycoprotein with properties expected of a fibronectin receptor. Cell 40:191-198.

Rønn LCB, Bock E, Linnemann D, Jahnsen H (1995) NCAM-antibodies modulate induction of long-term potentiation in rat hippocampal CA1. Brain Res 677:145-151.

Rosales C, O’Brien V, Kornberg L, Juliano R (1995) Signal transduction by cell adhesion receptors. Biochim Biophys Acta 1242:77-98.

Rosenmund C, Carr DW, Bergeson SE, Nilaver G, Scott JD, Westbrook GL (1994) Anchoring of protein kinase A is required for modulation of AMPA/kainate receptors on hippocampal neurons. Nature 368:853-856.

Rosenmund C, Westbrook GL (1993) Calcium-induced actin depolymerization reduces NMDA channel activity. Neuron 10:805-814.

Ruoslahti E, Pierschbacher MD (1987) New perspectives in cell adhesion: RGD and integrins. Science 238:491-497.

Schachner M, Martini R (1995) Glycans and the modulation of neuralrecognition molecule function. Trends Neurosci 18:183-191.

Schreiner CL, Bauer JS, Danilov YN, Hussein S, Sczekan MM, Juliano RL (1989) Isolation and characterization of Chinese hamster ovary cell variants deficient in the expression of fibronectin receptor. J Cell Biol 109:3157-3167.

Schwartz MA, Ingber DE (1994) Integrating with integrins. Mol Biol Cell 5:389-393.

Schwarz MA, Brown PJ, Eveleth DD, Bradshaw RA (1989) Modulation of growth factor induced fiber outgrowth in rat pheochromocytoma (PC12) cells by a fibronectin receptor antibody. J Cell Physiol 138:121-128.

Sheng M (1996) PDZs and receptor/channel clustering: rounding up the latest suspects. Neuron 17:575-578.

Sheppard A, Wu J, Rutishauser U, Lynch G (1991) Proteolytic modification of neural cell adhesion molecule (NCAM) by the intracellular proteinase calpain. Biochim Biophys Acta 1076:156-160.

Shimizu Y, Van Seventer GA, Horgan KJ, Shaw S (1990) Regulated expression and binding of three VLA $(\beta 1)$ integrin receptors on T cells. Nature 345:250-253.

Siess W (1989) Molecular mechanisms of platelet activation. Physiol Rev 69:58-178.

Staubli U, Chun D (1996) Factors regulating the reversibility of longterm potentiation. J Neurosci 16:853-860.

Staubli U, Lynch G (1987) Stable hippocampal long-term potentiation elicited by "theta" pattern stimulation. Brain Res 435:227-234.

Staubli U, Lynch G (1990) Stable depression of potentiated synaptic responses in the hippocampus induced by low frequency stimulation. Brain Res 513:113-118.

Staubli U, Vanderklish P, Lynch G (1990) An inhibitor of integrin receptors blocks long-term potentiation. Behav Neural Biol 53:1-5.

Tanaka Y, Albelda SM, Horgan KJ, van Seventer GA, Shimizu Y, Newman W, Hallam J, Newman PJ, Buck CA, Shaw S (1992) CD31 expressed on distinctive $\mathrm{T}$ cell subsets is a preferential amplifier of $\beta_{1}$ integrin-mediated adhesion. J Exp Med 176:245-253.

Wallace CS, Hawrylak N, Greenough WT (1991) Studies of synaptic structural modifications after long-term potentiation and kindling: context for a molecular morphology. In: Long-term potentiation: a debate 
of current issues (Baudry M, Davis JL, eds), pp 189-232. Cambridge: MIT.

Wang L-Y, Salter MW, MacDonald JF (1991) Regulation of kainate receptors by cAMP-dependent protein kinase and phosphatases. Science 253:1132-1135.

Wenthold RJ, Yokotani N, Doi K, Wada K (1992) Immunochemical characterization of the non-NMDA glutamate receptor using subunitspecific antibodies. J Biol Chem 267:501-507.

Wu C, Bauer JS, Juliano RL, McDonald JA (1993) The $\alpha_{5} \beta_{1}$ integrin fibronectin receptor, but not the $\alpha_{5}$ cytoplasmic domain, functions in an early and essential step in fibronectin matrix assembly. J Biol Chem 268:21883-21888.
Wu C, Chung AE, McDonald JA (1995a) A novel role for $\alpha_{3} \beta_{1}$ integrins in extracellular matrix assembly. J Cell Sci 108:2511-2523.

Wu C, Keivens VM, O’Toole TE, McDonald JA, Ginsberg MH (1995b) Integrin activation and cytoskeletal interaction are essential for the assembly of a fibronectin matrix. Cell 83:715-724.

Xiao P, Bahr BA, Staubli U, Vanderklish PW, Lynch G (1991) Evidence that matrix recognition contributes to the stabilization but not induction of LTP. NeuroReport 2:461-464.

Yakel JL, Vissavajjhala P, Derkach VA, Brickey DA, Soderling TR (1995) Identification of a $\mathrm{Ca}^{2+} /$ calmodulin-dependent protein kinase II regulatory phosphorylation site in non- $N$-methyl-D-aspartate glutamate receptors. Proc Natl Acad Sci USA 92:1376-1380. 